\title{
Pengaruh Efektivitas Jus Jambu Biji Merah Terhadap Peningkatan Kadar Haemoglobin Dengan Kejadian Anemia
}

\section{Effect of Effectiveness of Red Guava Juice On The Increase In Haemoglobin Levels With The Incidence Of Anemia}

\author{
Rismayani $^{1 \text {,* }^{*} \text {, Dita Selvianti }}{ }^{2}$ \\ 1,2 Akademi Kesehatan Yayasan Sapta Bakti, Jalan Mahakam Raya No 16 Lingkar Barat, Bengkulu 38221, Indonesia \\ 1rismayanibkl@gmail.com, ${ }^{2}$ ditaselvianti@yahoo.com \\ * corresponding author \\ Tanggal Submisi: . 1 Januari 2021, Tanggal Penerimaan: 6 Februari 2021
}

\begin{abstract}
Abstrak
Remaja putri termasuk rawan menderita anemia karena masa pertumbuhan dan setiap bulan mengalami menstruasi yang menyebabkan kehilangan zat besi. Tujuan penelitian ini untuk mengetahui kadar sebelum dan sesudah diberikan Jus Jambu Biji Merah. Metode penelitian ini dengan quasy ekperiment dengan pendekatan one group pre test dan post test dengan sampel 30 siswi yang mengalami Anemia. Hasil dari penelitian ini didapatkan 19 (63\%) orang mengalami anemia ringan, dan $11(37 \%)$ orang mengalami anemia. Setelah diberikan jus jambu biji selama 7 hari berturut-turut dari 30 responden, 27 (90\%) orang tidak mengalami anemia dan $3(10 \%)$ orang mengalami anemia ringan. Hasil Uji T didapatkan nilai $\mathrm{p}$ value sebesar $0,002(\mathrm{p}<0,05)$, sehingga dapat disimpulkan bahwa terdapat peningkatan kadar Haemoglobin.
\end{abstract}

Kata kunci : remaja; anemia; jus jambu biji

\begin{abstract}
Teenage girls are prone to suffer from anemia due to their growing period and menstruation each month which causes iron loss. The purpose of this study was to determine the levels before and after being given Red Guava Juice. This research method is a quasy experiment with a one group pre-test and post-test approach with a sample of 30 female students who experience anemia. The results of this study found that 19 (63\%) people had mild anemia, and $11(37 \%)$ people had anemia. After being given guava juice for 7 consecutive days from 30 respondents, 27 (90\%) people did not have anemia and $3(10 \%)$ people had mild anemia. The $\mathrm{T}$ test results obtained a p value of 0.002 ( $\mathrm{p}<0.05$ ), so it can be concluded that there is an increase in hemoglobin levels.
\end{abstract}

Keywords: teenagers; anemia; guava juice

\section{PENDAHULUAN}

Masa remaja ialah periode waktu individu beralih dari fase anak ke fase dewasa. Setiap manusia pasti akan mengalami masa remaja. Masa remaja terbagi menjadi tiga batasan umur yaitu remaja awal (12-15 tahun), remaja pertengahan (15-18 tahun), remaja akhir (1821 tahun) umur pada masa remaja yaitu 12-21 tahun. Pada remaja putri terjadi suatu 
perubahan fisik yaitu perubahan organ-organ reproduksi yang ditandai dengan datangnya menstruasi.

Pada beberapa penelitian yang telah dilakukan menunjukkan kelompok remaja yang mengalami banyak masalah gizi. Satu diantara bentuk permasalah gizi dan kesehatan remaja putri adalah anemia. Anemia merupakan penyakit yang sering diderita oleh masyarakat, baik anak-anak, remaja, ibu hamil maupun orang tua. Anemia adalah rendahnya sel darah merah atau konsentrasi haemoglobin $(\mathrm{Hb})$ yang mengakibatkan turunnya kemampuan darah untuk mengangkut oksigen.

Gejala dari anemia adalah cepat lelah ,pusing kepala, letih, lemas, sesak napas, mudah kesemutan, dan merasa mual. Berkurangnya jumlah hemoglobin dalam darah pada remaja dapat berdampak pada menurunnya produktivitas kerja ataupun menurunkan kemampuan untuk berkonsentrasi dengan baik sehingga akan menurunkan prestasi belajar.

Penanggulangan anemia gizi besi dapat dilakukan dengan pemberian tablet besi yang mengandung 30-60 mg zat besi dan $400 \mathrm{mg}$ asam folat. Tablet ini dapat diberikan setiap minggunya untuk memenuhi kebutuhan zat besi. Pemberian tablet besi dua kali perminggu selama dua bulan dapat meningkatkan kadar hemoglobin sebesar $0,99 \mathrm{~g} / \mathrm{dl}^{2}$. Vitamin $\mathrm{C}$ dapat meningkatkan $\mathrm{pH}$ didalam lambung sehingga dapat meningkatkan proses penyerapan zat besi hingga 30\%. Kandungan vitamin $\mathrm{C}$ yang paling tinggi terdapat didalam buah jambu biji. Dalam bahasa latin jambu ini dikenal dengan sebutan Psidium guajava, dan dalam bahasa Inggris disebut Guava. Kandungan vitamin $\mathrm{C}$ dalam jambu biji lebih tinggi dari buah jeruk, dalam 100 gram buah jambu biji ini mengandung $183,5 \mathrm{mg}$ vitamin $\mathrm{C}$, sedangkan pada 100 gram buah jeruk terkandung 50-70 mg vitamin C.

Dalam penelitian menyebutkan bahwa konsumsi jus jambu biji terbukti berpengaruh meningkatkan kadar $\mathrm{Hb}$ pada remaja yang mengalami anemia. Sejalan dengan penelitian ${ }^{5}$, Penyerapan zat besi sangat dipengaruhi oleh adanya vitamin $\mathrm{C}$ dalam tubuh remaja. Vitamin $\mathrm{C}$ dapat membantu mereduksi besi ferri $(\mathrm{Fe} 3+)$ menjadi ferro $(\mathrm{Fe} 2+)$ dalam usus halus sehingga mudah diabsorpsi tubuh, proses reduksi tersebut akan semakin besar jika $\mathrm{pH}$ didalam lambung semakin asam. Vitamin $\mathrm{C}$ dapat meningkatkan $\mathrm{pH}$ didalam lambung sehingga dapat meningkatkan proses penyerapan zat besi hingga 30\%. Kandungan vitamin $\mathrm{C}$ yang paling tinggi terdapat didalam buah jambu biji. Kandungan vitamin $\mathrm{C}$ dalam jambu biji lebih tinggi dari buah jeruk, dalam 100 gram buah jambu biji ini mengandung 183,5 mg vitamin C, sedangkan pada 100 gram buah jeruk terkandung 50-70 mg vitamin C.

Sejumlah hasil penelitian telah membuktikan manfaat jus jambu biji dibutuhkan untuk peningkatan kadar $\mathrm{Hb}$, mayoritas responden terjadi peningkatan kadar Hb dengan waktu yang dibutuhkan antara 6-7 hari, lamanya waktu yang dibutuhkan untuk peningkatan kadar $\mathrm{Hb}$ terlihat nyata Jus Jambu Biji Merah terhadap peningkatan kadar HB dengan kejadian Anemia. Berdasarkan latar belakang diatas maka peneliti tertarik untuk melakukan penelitian tentang Pengaruh Efektivitas Jus Jambu Biji Merah terhadap peningkatan kadar HB dengan kejadian Anemia.

\section{METODE PENELITIAN}

Penelitian ini menggunakan rancangan penelitian eksperimen semu (Quasi experiment) dengan pendekatan one group pre test-posttest design. Pemeriksaan $\mathrm{Hb}$ dilakukan sebelum pemberian jus jambu biji, kemudian setelah diberikan jus jambu biji selama 7 hari kemudian $\mathrm{Hb}$ dicek kembali pada hari ke 8 setelah perlakuan. Metode sampel pada penelitian ini menggunakan Purposive sampling adalah sampel yang diambil berdasarkan pada suatu pertimbangan tertentu yang dibuat oleh peneliti berdasarkan ciri atau sifat populasi yang sudah diketahuinya dengan jumlah sampel dalam penelitian ini 30 orang. Penelitian ini 
menggunakan data primer (data siswi yang mengalami anemia dan observasi peningkatan kadar $\mathrm{Hb}$ pada hari ke 8 setelah diberikan jus jambu biji selama 7 Hari berturut-turut).

Pada penelitian ini populasinya adalah seluruh remaja putri yang berada di kelas VIII di SMP 18 Kota Bengkulu yang berjumlah 65 orang. Teknik pengumpulan dilakukan dengan observasi lapangan dengan pengukuran dan pencatatan berkaitan dengan pengukuran $\mathrm{Hb}$ sebelum dan sesudah diberikan jus jambu biji. Jumlah Sampel yaitu 30 orang siswi yang mengalami anemia. Penelitian ini menggunakan data primer, data siswi yang mengalami anemia dan observasi peningkatan kadar $\mathrm{Hb}$ pada hari ke 8 setelah diberikan jus jambu biji selama 7 Hari berturut-turut yang memenuhi kreteria penelitian dijadikan sample. Setelah data terkumpul, dilakukan analisis univariat atau deskripsi (Distibusi Frekuensi) maupun analisis bivariat dengan uji $\mathrm{T}$ berpasangan.sedangkan kriteria ekslusi siswi yang tidak bersedia menjadi responden.

\section{HASIL DAN PEMBAHASAN}

Hasil dan Pembahasan mengandung paparan hasil analisis yang terkait dengan pernyataan dalam penelitian.Pembahasan berisi makna hasil dan perbandingan teori dan hasil penelitian serupa.Panjang Hail pemaran dan Pembahasan 40\% - 60\% dari panjang artikel.

Tabel 1. Kadar Hb sebelum pemberian Jus Jambu Biji ( $\mathrm{n}=30)$

\begin{tabular}{lll}
\hline \multicolumn{1}{c}{ Kadar Hb } & f & $\mathbf{( \% )}$ \\
\hline Anemia ringan $(9-10 \mathrm{gr} / \mathrm{dl})$ & 19 & $63 \%$ \\
Anemia sedang $(7-8 \mathrm{gr} / \mathrm{dl})$ & 11 & $37 \%$ \\
\hline
\end{tabular}

Sumber : data primer (2019), telah diolah

Berdasarkan tabel 1 diperoleh bahwa kadar $\mathrm{Hb}$ sebelum diberikan jus jambu biji diperoleh 63\% (19 Responden) mengalami anemia ringan, 37\% (11 Responden) mengalami anemia sedang. Hal ini sesuai dengan kriteria inklusi penelitian.

Tabel 2. Kadar Hb setelah pemberian Jus Jambu Biji (n-30)

\begin{tabular}{lcc}
\multicolumn{1}{c}{ Kadar Hb } & f & $\mathbf{( \% )}$ \\
\hline Tidak anemia $(\geq 11 \mathrm{gr} / \mathrm{dl})$ & 27 & $90 \%$ \\
Anemia Ringan 9-10 gr/dl & 3 & $10 \%$ \\
Anemia sedang 7-8gr/dl & 0 & $0 \%$ \\
\hline
\end{tabular}

Sumber : data primer (2019), telah diolah

Berdasarkan tabel 2 diperoleh bahwa kadar $\mathrm{Hb}$ setelah diberikan jus jambu biji diperoleh bahwa sebanyak 90\% (27 Responden) tidak mengalami anemia, 10\% ( 3 Responden) mengalami anemia ringan.

Tabel 3. Hasil Analisis Kadar Hb sebelum dan sesudah diberikan jus jambu biji $(n=30)$

\begin{tabular}{|c|c|c|c|}
\hline Variabel & Mean \pm Sd & Perbedaan Mean \pm Sd & P Value \\
\hline Kadar Hb sebelum intervensi & $11,4364 \pm 0,30945$ & & \\
\hline Kadar Hb setelah Intervensi & $11,9955 \pm 0,79790$ & $0,559 \pm 0,724$ & 0,002 \\
\hline
\end{tabular}

Sumber : data primer (2019), telah diolah

Berdasarkan tabel 3 dapat disimpulkan bahwa hasil uji statistik dengan menggunakan Uji $\mathrm{T}$ berpasangan didapatkan nilai $\mathrm{p}=0,002$, maka ada perbedaan yang signifikan antara sebelum dan sesudah diberikan jus jambu biji dengan demikian menunjukan bahwa terdapat pengaruh jus jambu biji terhadap kadar $\mathrm{Hb}$ siswi yang mengalami anemia yaitu untuk meningkatkan kadar $\mathrm{Hb}$ 


\section{PEMBAHASAN}

\section{Kadar Hb sebelum diberikan Jus Jambu Biji}

Berdasarkan hasil penelitian yang dikumpulkan melalui lembar observasi kadar $\mathrm{Hb}$ pada tabel 1 menunjukkan rata-rata siswi mengalami anemia, dimana anemia ringan sebanyak 19 siswi, dan 11 siswi mengalami anemia sedang.

Menurut Manuaba (2010) Anemia Ringan adalah suatu kondisi medis dimana jumlah sel darah merah atau $\mathrm{Hb}$ 9-10 gr/dl sedangkan anemia sedang adalah suatu kondisi dimana sel darah merah atau $\mathrm{Hb}$ 7-8 gr/dl. Salah satu faktor yang mempengaruhi kejadian anemia pada remaja putri yaitu saat usia remaja dimana pada usia ini membutuhkan peningkatan kebutuhan zat besi karena percepatan pertumbuhan dan menstruasi. Selain itu, remaja putri biasanya sangat memperhatikan bentuk badan, sehingga banyak membatasi konsumsi makan dan melakukan pantangan terhadap banyak makanan (Sarlitowirawan,2010). Salah satu faktor yang mempengaruhi kejadian anemia sebagaimana ditunjukkan oleh Manuaba, 2010 adalah defesiensi vitamin A, faktor lain yaitu kurangnya konsumsi energi dan protein juga dapat menurunkan kadar $\mathrm{Hb}$ dalam darah.

\section{Kadar Hb setelah diberikan Jus jambu Biji}

Berdasarkan hasil penelitian yang dikumpulkan melalui lembar observasi kadar $\mathrm{Hb}$ pada tabel 2 menunjukkan rata-rata siswi tidak mengalami anemia sebanyak 27 siswi, dan ada 3 siswi masih mengalami anemia ringan setelah pemberian jus jambu biji. Pendidikan bukan merupakan faktor yang dominan terhadap kejadian anemia pada remaja, karena meskipun mempunyai pendidikan yang tinggi akan tetapi bila perilaku yang mendukung terhadap pencegahan anemia masih rendah, misalnya tidak bisa mengkonsumsi sayuran hijau, tidak minum tablet tambah darah secara rutin selama haid, maka akan tetap mengalami anemia. Sebaliknya bagi wanita yang mempunyai pendidikan rendah namun konsumsi makanan zat besinya tinggi, maka akan terhindar dari anemia. Pendidikan juga akan menentukan tingkat pengetahuan seseorang. Paling tidak kemampuan berfikir seseorang dengan pendidikan tinggi akan lebih luas.

\section{Kadar Hb sebelum dan setelah diberikan Jus Jambu Biji}

Hasil penelitian yang dilakukan pada siswi SMP 18 Kota Bengkulu didapatkan hasil uji statistik menggunkan uji $\mathrm{T}$ berpasangan sesudah pemberian intervensi jus jambu biji selama 7 hari berturut-turut di peroleh Pvalue $=0,002<\alpha(0,05)$, sehingga dapat disimpulkan bahwa terdapat peningkatan kadar $\mathrm{Hb}$ sesudah dilakukannya intervensi pemberian jus jambu biji.

Anemia gizi disebabkan oleh kekurangan zat gizi yang berperan dalam pembentukan hemoglobin,baik karena kekurangan konsumsi atau karena gangguan absorpsi. Zat gizi yang bersangkutan adalah besi, protein, piridoksin (vitamin B6) yang berperan sebagai katalisator dalam sintesis hem di dalam molekul hemoglobin, vitamin $\mathrm{C}$ yang mempengaruhi absorpsi dan pelepasan besi dari transferinke dalam jaringan tubuh dan vitamin $\mathrm{E}$ yang mempengaruhi membran sel darah merah.

Dampak anemia bagi remaja putri adalah menurunkan kemampuan dan konsentrasi belajar, mengganggu pertumbuhan sehingga tinggi badan tidak mencapai optimal, menurunkan kemampuan fisik olahraga dan mengakibatkan muka pucat.

Kadar $\mathrm{Hb}$ yang rendah kebanyakan disebabkan oleh pola makan. Misalnya kurang nutrisi atau zat yag penting seperti zat besi, vitamin B12, vitamin $\mathrm{C}$ hingga asam folat sebagai bagian dari produksi sel darah merah.selanjutnya akibat dari wanita biasanya sedang dalam masa haid. Selebihnya disebabkan oleh penyakit atau kelainan seperti radang usus, gastritis, radang kronis sampai thalasemia

Hasil tersebut menunjukkan bahwa intervensi pemberian jus jambu biji terhadap kadar $\mathrm{Hb}$ siswi yang mengalami anemia memiliki efek untuk meningkatkan kadar $\mathrm{Hb}$. Hal ini 
dikarenakan jambu biji mempunyai kandungan vitamin $\mathrm{C}$ lima kali lebih banyak daripada kandungan vitamin $\mathrm{C}$ dalam buah jeruk. Selain itu, kandungan vitamin A buah ini tergolong tinggi dengan kadar gula 8\%. Kandungan gizi buah jambu biji merah (100 gr) adalah 49 kalori, vitamin A 25 SI, vitamin B1 0,02 mg, vitamin C $87 \mathrm{mg}$, kalsium $14 \mathrm{mg}$, hidrat arang 12,2 gram, fosfor $28 \mathrm{mg}$, besi $1,1 \mathrm{mg}$, protein $0,9 \mathrm{mg}$, lemak 0,3 gram, dan air 86 gram. Peranan vitamin $\mathrm{C}$ dalam proses penyerapan zat besi yaitu membantu mereduksi besi ferri (Fe3+) menjadi ferro ( $\mathrm{Fe} \mathrm{2+)}$ dalam usus halus sehingga mudah diabsorbsi, proses reduksi tersebut akan semakin besar bila $\mathrm{pH}$ didalam lambung semakin asam. Vitamin $\mathrm{C}$ dapat menambah keasaman sehingga dapat meningkatkan penyerapan zat besi hingga 30\%.Vitamin $\mathrm{C}$ menghambat pembentukan hemosederin yang sukar dimobilisasi untuk membebaskan besi bila diperlukan.Absorbsi besi dalam bentuk nonheme meningkat empat kali lipat bila ada vitamin $\mathrm{C}$, sehingga dapat mempengaruhi $\mathrm{Fe}$ dalam darah dan diharapkan terjadinya peningkatan $\mathrm{Hb}$.

Meskipun secara statistik terdapat pengaruh antara pemberian jus jambu biji terhadap peningkatan kadar $\mathrm{Hb}$, tetapi terdapat 3 responden yang tidak mengalami peningkatan kadar $\mathrm{Hb}$ karena pada saat dilakukan penelitian siswi tersebut mengalami menstruasi sehingga terjadi penurunan kadar $\mathrm{Hb}$ sekitar 0,25-0,5 gr/dl dan jus jambu biji tidak dapat meningkatkan kadar $\mathrm{Hb}$, tetapi hanya dapat mengembalikan kadar $\mathrm{Hb}$ semula saja.

Hasil penelitian ini sesuai dengan penelitian yang pernah dilakukan dengan judul pengaruh pemberian jambu biji terhadap kadar $\mathrm{Hb}$ pada remaja putri yang mengalami anemia.

Hal ini sejalan dengan yang menyatakan bahwa konsumsi buah jambu biji sebagai sumber vitamin $\mathrm{C}$ dapat membantu meningkatkan penyerapan zat besi, akan tetapi jika asupan vitamin $\mathrm{C}$ rendah, dapat memberikan implikasi terhadap kadar $\mathrm{Hb}$.

Berdasarkan penjelasan diatas maka peneliti berpendapat bahwa jus jambu biji dapat berpengaruh terhadap kadar $\mathrm{Hb}$ pada siswi yang mengalami anemia.

\section{SIMPULAN}

Berdasarkan hasil penelitian dapat ditarik kesimpulan bahwa Kadar Hb sebelum diberikan jus jambu biji pada siswi rata-rata mengalami anemia ringan 19 (63\%) orang dan anemia sedang 11 (37\%) orang. Kadar $\mathrm{Hb}$ setelah diberikan jus jambu biji pada siswi ratarata mengalami peningkatan kadar $\mathrm{Hb}$, dari 30 responden hanya $3(10 \%)$ orang yang masih mengalami anemia ringan . Terdapat Pengaruh kosumsi jus jambu biji terhadap peningkatan kadar $\mathrm{Hb}$ pada remaja yang mengalami anemia

\section{SARAN}

Berdasarkan hasil penelitian yang telah dilakukan, ada beberapa saran yang dapat diberikan, yaitu

1. Hasil penelitian ini dapat dijadikan data dasar bagi peneliti selanjutnya terkait masalah gizi pada remaja untuk peningkatan kadar Hb remaja yang mengalami anemia

2. Hasil penelitian ini dapat dijadikan edukasi untuk kepentingan program khususnya terkait pemantauan efektifitas konsumsi jus jambu biji terhadap peningkatan kadar $\mathrm{Hb}$ pada remaja yang mengalami anemia

3. Diharapkan dapat menambah wawasan khususnya pada remaja yang mengalami anemia dengan melakukan penyuluhan pada remaja sebagai bentuk upaya promosi dan preventif untuk menanggulangi dan meminimalkan angka kejadian anemia .

\section{REFERENCE}

Almatsier, S. (2011). Prinsip Dasar Ilmu Gizi. Jakarta : PT. Gramedia Pustaka Utama. 
Arifatul. (2010). Pengaruh Pemberian Jus Kacang Hijau dengan Jus Jambu Biji Terhadap Kadar Hemoglobin [online]. Dari :http://studentresearch.umm.ac.id/print/student_research_3885.html.pp.1

Arifin, H., Agustina. dan Rizal, Z. (2013). Pengaruh Pemberian Jus Jambu Biji Merah (Psidium Guajava L.) Terhadap Jumlah Sel Eritrosit, Hemoglobin, Trombosit dan Hematokrit Pada Mencit Putih. Jurnal Sains dan Teknologi Farmasi, Vol. 18, No.1.

Arisman.(2010). Gizi dalam daur kehidupan. Buku Ajar Ilmu Gizi. Jakarta: EGC.

Astuti, Hidayanti, Lina. (2014). Pengaruh Suplementasi Fe dan Vitamin C Terhadap Peningkatan Kadar Hemoglobin. Peminatan Gizi Fakultas Kesehatan Masyarakat Universitas Siliwangi.

Djaelani Achmad, (2016). Ilmu Gizi Untuk Mahasiswa dan Profesi. Jakarta. Dian Rakyat.

Hardimarta. (2016). Pengaruh Jus Jambu Biji Merah dalam Meningkatkan Kadar Hemoglobin.

Ibrahim et al.(2006). Defisiensi Besi. Jakarta : Gramedia

Kumalasari, Intan \& Iwan Andhyantoro.(2012). Kesehatan Reproduksi untuk Mahasiswa Kebidanan dan Keperawatan. Jakarta: Salemba Medika.

Manuaba IBG.I.A, Manuaba C, Manuaba IBG.F. (2010). Pengantar Kuliah Obstetri. Jakarta: Buku Kedokteran EGC P 38

Notoatmodjo,S. (2010). Metodologi Penelitian Kesehatan. Jakarta: Rieneke Cipta.

Putro, K. Z. (2017). Memahami Ciri dan Tugas Perkembangan Masa Remaja. APLIKASIA: Jurnal Aplikasi Ilmu-ilmu Agama, Vol. 17, No. 1, 1-8.

Proverawati, Asfuah S. (2011). Buku Ajar Gizi untuk Kebidanan. Yogyakarta: Nuha Medika.

Rhamnosa. (2014). Kenali Vitamin C. November 2017

Sambou CN, Yamlean PVY, Lolo WA. (2014). Uji efektivitas jus buah jambu biji merah (Psidium guajava, Linn) terhadap kadar hemoglobin (HB) darah tikus putih jantan galur wistar (Rattus norvergicus L.). Jurnal Ilmiah Farmasi - Unsrat. Vol 3 no 3 hal :220-1.

Sediaoetama, AD. (2003). Ilmu Gizi untuk Mahasiswa dan Profesi. Jilid I. M. Sc. Jakarata: Dian Rakyat.

Sianturi, C. (2012). Pengaruh Vitamin C pada Penyerapan Zat Besi Non Heme. Medan: FMIPA UNM.

Tyastuti, S., \& Wahyuningsih, H. P. (2016). Asuhan Kebidanan Kehamilan. Jakarta: Pusdik SDM Kesehatan. 